\title{
The Development of Pocketbook Learning Media based on Mind Mapping in Introductory Economics Course
}

\author{
Muhammad Hasan ${ }^{1, *}$, Tuti Supatminingsih ${ }^{1}$, Mustari ${ }^{1}$, M. Ihsan Said Ahmad ${ }^{1}$, Syamsu Rijal ${ }^{1}$, \\ Muhammad Imam Ma'ruf'
}

\begin{abstract}
${ }^{1}$ Department of Economics Education, Faculty of Economics, Universitas Negeri Makassar, 90222, South Sulawesi, Indonesia ${ }^{2}$ Department of Economics Development, Faculty of Economics, Universitas Negeri Makassar, 90222, South Sulawesi, Indonesia *Corresponding Author: m.hasan@unm.ac.id
\end{abstract}

Received October 15, 2020; Revised December 1, 2020; Accepted December 17, 2020

\section{Cite This Paper in the following Citation Styles}

(a): [1] Muhammad Hasan, Tuti Supatminingsih, Mustari, M. Ihsan Said Ahmad, Syamsu Rijal, Muhammad Imam Ma'ruf, "The Development of Pocketbook Learning Media Based on Mind Mapping in Introductory Economics Course," Universal Journal of Educational Research, Vol. 8, No. 12B, pp. 8274-8281, 2020. DOI: 10.13189/ujer.2020.082632.

(b): Muhammad Hasan, Tuti Supatminingsih, Mustari, M. Ihsan Said Ahmad, Syamsu Rijal, Muhammad Imam Ma'ruf (2020). The Development of Pocketbook Learning Media Based on Mind Mapping in Introductory Economics Course. Universal Journal of Educational Research, 8(12B), 8274-8281. DOI: 10.13189/ujer.2020.082632.

Copyright $\bigcirc 2020$ by authors, all rights reserved. Authors agree that this article remains permanently open access under the terms of the Creative Commons Attribution License 4.0 International License

\begin{abstract}
Economic learning at the tertiary level, especially in the introductory economics course at the Faculty of Economics, is still limited to textbooks or foreign translations. They are structurally difficult for students to understand because they use case studies that do not follow local reality conditions in Indonesia, especially those which are related to data and economic phenomena. Therefore, we need a book that is interesting, innovative, concise, and easy to learn. This study focused on developing a handbook as learning media based on mind mapping on the introductory economics course and assessing the feasibility of the mind mapping-based learning media book for use in an introductory course to economics, primarily on necessary economic concept study contents. This research used Research and Development (R \& D) model in developing a mind mapping-based economics pocketbook as learning media. The development of a mind mapping-based pocketbook will make students easier to study in the introductory economics course because the small pocketbook will make students easy to study anywhere and anytime. The development of the pocketbook product consisted of five stages: analysis, design, development, implementation, and evaluation. Based on the validation conducted by the content experts and media experts on content and linguistic feasibility, the mind mapping-based pocketbook on the introductory economics course at the Faculty of Economics at Universitas Negeri Makassar was in a very feasible category. The product trial results showed that mind
\end{abstract}

mapping based pocketbook was very viable in terms of content, linguistic, presentation, and graphic so that the pocketbook that has been tested was ready to be published.

Keywords Learning Media, Pocketbook, Mind Mapping, Introduction to Economics

\section{Introduction}

Economic education focuses on economics as knowledge content and learning activities as a subject for learning [1]. It includes economic content to be taught (economic knowledge provided), economic learning methods (pedagogical content knowledge), design of learning assessment and evaluation practices (assessment objectives, tools, and strategies), and information that will appeal to economic educators at many levels of education such as primary education, junior secondary education, senior secondary education, and higher education [2]. Economic education aims to create responsible citizens, influential decision-makers, and rational voters in any dynamic economic environment.

Economic education is a crucial subject that tends to be neglected by many educational institutions at various levels. The importance of economic education goes far beyond increasing understanding of the basic principles of demand, supply, and market mechanisms. Economics can 
be taught by generating new knowledge through students' exploration of the environment and learning experiences in their real life. Students developed their perceptions of the economic world from an early age and continued to process it through the educational process until their perceptions of the economic world developed into attitudes and opinions on the subject of economics [3]. In this process, educators as managers in learning activities are considered to influence the attitude development. Walstad dan Rebeck argued that economic knowledge was essential for economic growth and development [4].

Industrial Revolution 4.0 has changed the lives of many people in socio-economic aspects. Economic educators need to equip students to become the future workforce because in the Industrial Revolution 4.0 there will be many new professions that do not exist in the current era. Apart from this, economic educators also need to equip students with an understanding of how the economy works and knowledge on how economic mechanisms can affect various complex aspects of life, from small businesses to large companies. By finding better economic learning, educators contribute to improve students' economic attitudes. By teaching useful basic economic concepts and applying them in real life, it is hoped that students can become the right decision-makers on various dynamic economic issues. The more economic concepts students know, the more they will like the various information they have about economic problems. Students who do not get the opportunity to study economics and improve their understanding on economics will never be interested in their economic world. Economic education is critical because economic education is essential to determine economic progress in the future [3].

Related to economic education at the higher education level, several problems determine students' learning quality, including introductory learning in economics in tertiary institutions. Lack of time management, study habits, ability to analyse problems, and analytical skills of mathematical reasoning in economics are some of the problems that often become obstacles in economic learning activities. These problems have impact on the low competence of students in terms of economic analysis and reasoning skills that are needed, either for mathematics or for non-mathematics in the curriculum, especially those which are related to the logical sequence of economic arguments in verbal or graphic form [5] [6] [7] [8].

An introductory economics course is a course that examines the basic concepts of economics, both micro and macro. In a micro perspective, an introductory course of economics includes the notion of economics, market mechanisms (demand and supply), the concept of elasticity, producer behaviour theory, consumer behaviour theory, production theory, production cost theory, and firm balance, while in a macro perspective, an introductory course of economics covered the main problems of macroeconomics, national income, balance in the economy, international economy, and economics development [9] [10].

Economics is a discipline dominated by a focus on the allocation and distribution of productive resources with particular attention to the use of these resources to increase income, welfare, and change behaviour in an interactive or market environment. The complexity and interaction of phenomena that occur in economics study need cooperation from various scientific disciplines. The prerequisite for interdisciplinary cooperation is to complement each other to achieve scientific progress and interpret various economic phenomena that consist of economic variables and various social variables. Interdisciplinary in economics begins at the level of scientific research and then it extends to the field of learning. The relationship between epistemological and learning aspects is starting to get more attention because these two aspects examine the process of where knowledge is built or formed. These interdisciplinary scientific relations positively impact the changing of economics learning paradigm, especially in introductory economics courses.

The conventional economic learning process makes educators a source of knowledge. Learners acquire knowledge by receiving information from educators. As objects in the learning activities, students acquire knowledge passively. Their initiative was not fully mobilized. The economic metrics obtained can not be used by students to solve practical economic problems. In conventional classroom learning, the primary source of knowledge is from books. Learners can not do anything except that they accept it passively, without chance for making innovation. Thus, such learning practices should begin to be abandoned.

The key to learning economics in higher education is mostly determined by the lecturers' efficiency and competence and the learning methods used, especially in introductory economics courses. Indonesia's higher education curriculum policy uses a national curriculum based on higher education competencies regarding the Indonesian National Qualifications Framework (KKNI). This curriculum uses a problem-based approach and requires lecturers to make a practical paradigm shift using active participative and active teaching methods. Students should be encouraged to collect relevant information and turn this information into marketable knowledge through new approaches and changing learning concepts, including economic learning [11]. The occurrence of a change in the learning paradigm including, lecturers' mastery of contents, learning approaches, learning models, learning strategies, assessment strategies, and the availability of excellent resources, can improve students' performance in learning [12] [13].

One aspect that needs to get significant attention in changing the learning paradigm is the learning media used. Learning media is a means used by lecturers to convey various learning materials to students so that they are 
easier to convey. In learning activities, the media has an important role in optimizing communication between lecturers and students in economic learning. The use of learning media in economic learning on economic courses needs to be packaged creatively, innovatively, attractively and tailored to students' needs to match learning outcomes: namely attitudes, general skills, knowledge, and specific skills.

Teaching materials in learning economics at the tertiary level, especially in economics courses at the Faculty of Economics, were still limited to foreign textbooks or translations, which are structurally tricky for students to understand. The case studies used do not follow local reality conditions in Indonesia, especially those which are related to economic data and phenomena. Therefore it is necessary to provide a book that is interesting, innovative, concise, and easy to learn. Students can add references and their insights into understanding the contents contained in introductory economics courses independently and quickly. The development of a mind mapping-based pocketbook is a solution that can later be used by students in learning the introductory economics course. The development of a mind mapping-based pocketbook will make students easier to study the introductory economics course because the small pocketbook will make students easy to study anywhere and anytime. Its attractive presentation will also increase students' interest in learning.

Mind mapping-based pocketbook as learning media reflects case-based learning characteristics, which can help improve students' abilities. Economics contents contained in the introductory economics course emphasize practice and theory. Without support from practice, the theory is like water without sources or trees without roots. Thus, to explain economic principles, lecturers need to mobilize a large number of cases in learning. Using a mind mapping-based pocketbook learning media in economic learning can display cases dynamically and clearly through mind mapping. Learning economics with mind mapping-based pocketbook learning media is more flexible and optional. Students can seek and have new sources of relevant knowledge through mind mapping. It can also help to create an interactive learning environment.

Based on this description, this study focused on developing a mind mapping-based pocketbook as learning media in the introductory economics course and assessing the appropriateness of the mind mapping-based pocketbook as learning media for use in the introductory economics course, primarily on learning content for basic economic concepts.

\section{Research Method}

This research used Research and Development (R \& D) method that produced a specific product and tested its effectiveness to develop a new product or enhance an existing and accountable product. Research-based product development consisted of five main steps: need analysis of product development, product design as well as testing its feasibility, product implementation or product manufacturing according to the design results, product testing or evaluation, and continuous revision. The researchers developed a mind mapping-based economic pocketbook as a learning medium in this research and development. The economics pocketbook product was then tried out to students in order to increase their learning motivation.

The subjects of this research and development were two material experts, two media experts, two lecturers of the introductory economics course, and 112 students of class 2019 batch who enrolled in the introductory course in the odd semester of 2019/2020 academic year in the Economic Education Study Program Makassar Class and Pare-Pare Class, Faculty of Economics, Universitas Negeri Makassar.

The data collected in this study consisted of two data. The first data was quantitative, namely data regarding the quality of mind mapping-based economic pocketbook product as a learning medium based on content experts, media experts, lecturers in the introductory economics course, and students. The second data was qualitative data. It was criticism and suggestions on developing a pocketbook based on mind mapping as a learning medium from content experts, media experts, lecturers in the introductory economics course, and students. Based on the development model used, the pocketbook product was developed for one academic year, starting from the even semester of the 2018/2019 academic year to the odd semester of the 2019/2020 academic year.

The research procedure referred to the ADDIE development model [14], a development model consisting of five stages. The ADDIE development model is an acronym for: analysis, design, development, implementation, and evaluation. The main characteristic of this development model is systematic because in this model, the output of the previous process becomes the input for the next process [15].

According to Molenda [15], the ADDIE development model began with a need analysis, an activity to survey the development scope to determine what needs needed to be priorities and development goals. The design stage was a stage where development objectives were designed to form a blueprint (design). In the next stage or the development stage, the existing blueprints were then realized using various specific tools or contents. In the implementation stage, procedures or equipment that had been compiled in the development stage were then realized in a real sense within the scope or context of the study. The evaluation stage was a stage where the 
developers carried out evaluation activities in order to find out the extent to which the development of the pocketbook was carried out by referring to the objectives that had been formulated in the previous stage, whether the development product was still in line with the objectives or there were still somethings that needed to be improved. At this stage, revision could be done to the aspects which were necessary to improve. The ADDIE development model scheme is illustrated in Figure 1.

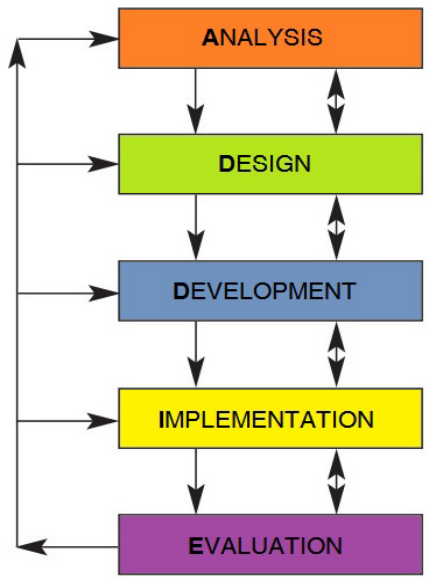

Source: Sink [14]

Figure 1. ADDIE Development Model

In this study, the data were collected using media assessment instruments distributed to the content experts, the media experts, the lecturers in the introductory economics course, and the students. The item specification of learning media assessment instruments can be seen in Table 1, Table 2, and Table 3.

Table 1. Media Assessment Instrument Grid for Content Experts

\begin{tabular}{|c|l|l|}
\hline No. & Component(s) & \multicolumn{1}{c|}{ Indicators } \\
\hline & & $\begin{array}{l}\text { a. Suitability of content with learning } \\
\text { outcomes } \\
\text { b. Suitability of the content with the study } \\
\text { content } \\
\text { c. The suitability of the content with the } \\
\text { indicators of the course and learning } \\
\text { achievement } \\
\text { d. The suitability of the content with the } \\
\text { learning objectives of the course } \\
\text { e. The truth of facts and concepts } \\
\text { f. Clarity of content delivery } \\
\text { g. Systematics of content delivery } \\
\text { eligibility }\end{array}$ \\
& & $\begin{array}{l}\text { h. Completeness of the content } \\
\text { i. Content attractiveness } \\
\text { j. Figure and table functions }\end{array}$ \\
& $\begin{array}{l}\text { a. Suitability with student development } \\
\text { b. The correct use of mathematical terms } \\
\text { and symbols } \\
\text { c. Clarity of use of words and language } \\
\text { d. The suitability of using sentences with } \\
\text { Indonesian rules } \\
\text { e. Ease of understanding the flow of the } \\
\text { content } \\
\text { f. Coherence and order of thought } \\
\text { g. Ability to stimulate motivation }\end{array}$ \\
& &
\end{tabular}

Table 2. Media Assessment Instrument Grid for Media Experts

\begin{tabular}{|c|c|c|}
\hline No. & Component(s) & Indicators \\
\hline 1 & $\begin{array}{c}\text { Presentation } \\
\text { eligibility }\end{array}$ & $\begin{array}{l}\text { a. Presentation of content by the } \\
\text { systematics of writing } \\
\text { b. Logical presentation } \\
\text { c. Presentation sequence } \\
\text { d. Presentation of pictures, tables, and } \\
\text { symbols } \\
\text { e. Completeness of the presentation }\end{array}$ \\
\hline 2 & $\begin{array}{l}\text { Graphic } \\
\text { eligibility }\end{array}$ & $\begin{array}{l}\text { a. Pocketbook size } \\
\text { b. Use of letters } \\
\text { c. Use of color } \\
\text { d. Readability of writing sentences } \\
\text { e. Book cover design } \\
\text { f. Book content design }\end{array}$ \\
\hline
\end{tabular}

Table 3. Media Assessment Instrument Grid for Lecturers and Students

\begin{tabular}{|c|c|c|}
\hline No. & Component(s) & Indicators \\
\hline 1 & $\begin{array}{c}\text { Content } \\
\text { eligibility }\end{array}$ & $\begin{array}{l}\text { a. Clarity of learning outcomes } \\
\text { b. The relationship between content and } \\
\text { everyday life } \\
\text { c. Completeness of the content } \\
\text { d. Content attractiveness }\end{array}$ \\
\hline 2 & $\begin{array}{l}\text { Language } \\
\text { eligibility }\end{array}$ & $\begin{array}{l}\text { a. The accuracy of using terms and } \\
\text { symbols } \\
\text { b. Clarity of sentences } \\
\text { c. Use of communicative language } \\
\text { d. Presentation sequence } \\
\text { e. Ability to stimulate motivation }\end{array}$ \\
\hline 3 & $\begin{array}{c}\text { Presentation } \\
\text { eligibility }\end{array}$ & $\begin{array}{l}\text { a. Presentation of content by the } \\
\text { systematics of writing } \\
\text { b. Logical presentation } \\
\text { c. Presentation sequence } \\
\text { d. Presentation of figures, tables, and } \\
\text { symbols } \\
\text { e. Completeness of the presentation }\end{array}$ \\
\hline 4 & $\begin{array}{l}\text { Graphic } \\
\text { eligibility }\end{array}$ & $\begin{array}{l}\text { a. Pocketbook size } \\
\text { b. Attractive pocketbook design } \\
\text { c. The practicality of a pocketbook } \\
\text { d. Use of letters } \\
\text { e. Use of color } \\
\text { f. Limitations of writing sentences } \\
\text { g. The font size is proportional to the size } \\
\text { of the book } \\
\text { h. Interesting pocketbook cover }\end{array}$ \\
\hline
\end{tabular}

The data in this research were obtained through questionnaires in the form of assessment scores from the content experts, the media experts, and the lecturers in the introductory economics course. After that, the data were then analyzed to determine the products' assessment and opinions through product feasibility analysis with the criteria presented in Table 4.

Table 4. Assessment Criteria

\begin{tabular}{|c|c|}
\hline Average Score & Media Eligibility Assessment Criteria \\
\hline$>4.2-5.0$ & Very Feasible \\
\hline$>3.4-4.2$ & Feasible \\
\hline$>2.6-3.4$ & Enough \\
\hline$>1.8-2.6$ & Less \\
\hline $1.0-1.8$ & Very less \\
\hline
\end{tabular}




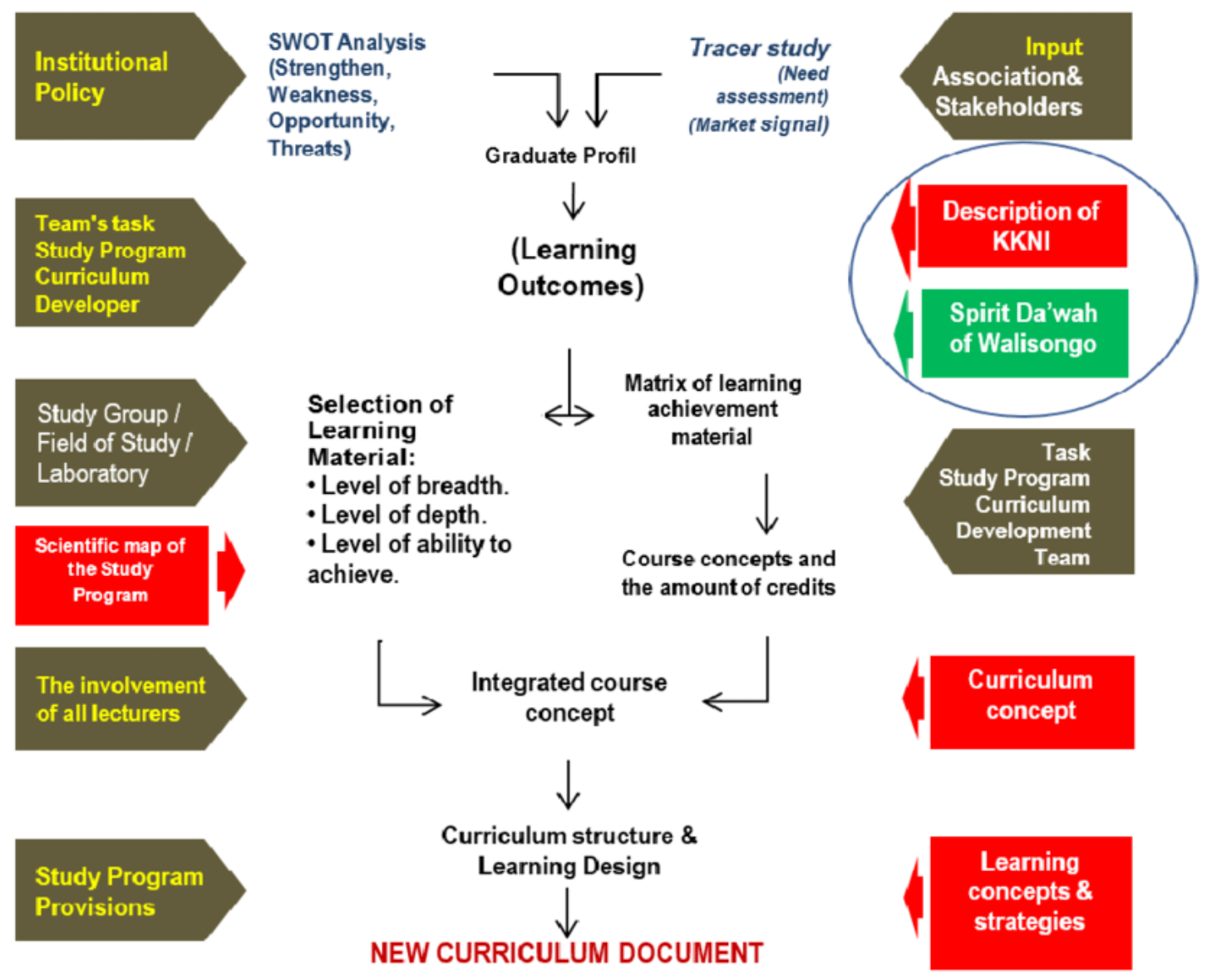

Figure 2. Stages of Media Development Needs Analysis

\section{Result and Discussion}

The development of mind mapping-based pocketbook media in the introductory economics course in the Economic Education Study Program of the Faculty of Economics, Universitas Negeri Makassar consisted of five stages: analysis, design, development, implementation, and evaluation.

In the needs analysis stage, a number of analyses were performed. A national curriculum analysis based on higher education competencies was carried out concerning the Indonesian National Qualifications Framework (KKNI) in the needs analysis stage. This curriculum is applied in the Economic Education Study Program, Faculty of Economics, Universitas Negeri Makassar. Besides curriculum analysis, analysis of student needs, analysis of study contents as well as subject matter in the introduction to economics, and formulation of goals to be achieved in the development of a mind mapping-based pocketbook as an alternative learning medium in the introductory economics course were also performed. Based on these analyses, it was found out that in the introductory economics course, the basic concepts of economics required learning media that were effective, practical, and easy to use for lecturers and students to support the learning outcomes. These stages can be seen in Figure 2.

At the design stage, a mind mapping-based pocketbook was designed to be developed. The mind mapping-based pocketbook product design included appearance, language, size, and content adjusted to learning outcomes in the introductory economics course. The mind mapping-based pocketbook was designed with an attractive appearance and language that was easy for students to understand and contained practical and systematic contents. It was easy for students to remember. At this stage, the mind mapping-based pocketbook design as a learning medium was still in the form of a prototype which needed further development steps.

At this stage, the pocketbook was designed with an attractive appearance and easy to understand the language that are contained in the learning materials and exercises related to basic economic concepts. Furthermore, relevant literatures were collected as references in devising a pocketbook framework with the content on basic economic concepts. The preparation of the contents of the pocketbook contents were adjusted to the learning outcomes and learning materials.

A mind mapping-based pocketbook was made at the development stage, which was used as a learning medium in the introductory economics course. At this stage, an 
instrument was made to measure the performance of the pocketbook product. Furthermore, the book was validated by several experts, including content experts, media experts, and lecturers in the introductory economics course. The validation process generated suggestions, comments, and inputs that were used to analyze and revise the developed media. The editing was aimed to avoid mistakes in the pocketbook, such as content errors, language errors, and misrepresentations. The results of the feasibility assessment of the mind mapping-based pocketbook on the introductory economics course from validators i.e. content experts and media experts can be seen in Table 5.

Table 5. Validation Result by Validator

\begin{tabular}{|c|c|c|c|c|}
\hline \multirow{2}{*}{$\begin{array}{c}\text { Eligibility } \\
\text { Aspects }\end{array}$} & \multicolumn{2}{|c|}{ Average Score } & \multirow[b]{2}{*}{ Score } & \multirow[b]{2}{*}{ Category } \\
\hline & $\begin{array}{c}\text { Content } \\
\text { Expert } \\
\end{array}$ & $\begin{array}{l}\text { Media } \\
\text { Expert }\end{array}$ & & \\
\hline Content & 4.80 & - & A & $\begin{array}{c}\text { Very } \\
\text { Feasible }\end{array}$ \\
\hline Language & 4.70 & - & A & $\begin{array}{c}\text { Very } \\
\text { Feasible }\end{array}$ \\
\hline Presentation & - & 4.60 & A & $\begin{array}{c}\text { Very } \\
\text { Feasible }\end{array}$ \\
\hline Graphical & - & 4.80 & A & $\begin{array}{c}\text { Very } \\
\text { Feasible }\end{array}$ \\
\hline Average score & 4. & & A & $\begin{array}{c}\text { Very } \\
\text { Feasible }\end{array}$ \\
\hline
\end{tabular}

Source: Computed data, 2020

Based on the results of the validation carried out by content experts and media experts, it was found out that the average content and linguistic feasibility aspect scores, respectively, 4.80 and 4.70 , with very feasible categories. The presentation and graphic aspects, respectively, got a score of 4.60 and 4.80 with very feasible categories. The assessment carried out by content experts and media experts in each aspect was very feasible. Overall, the average score obtained was 4.72 , so it can be concluded that the mind mapping-based pocketbook in the introductory economics course was in the very feasible category.

At the implementation stage, the pocketbook product that has been revised and declared feasible was then applied to the actual conditions, namely the introductory course on the odd semester of the 2019/2020 academic year at the Economic Education Study Program, Faculty of Economics, Universitas Negeri Makassar. The content presented was under the new media being developed. This stage was aimed to determine the response of the lecturers and the students to the pocketbook as a medium for learning. The limited trial was conducted to measure the feasibility of the pocketbook.

The trial was carried out on the subject class (study group), namely the class of the students who enrolled on the introductory economics course at the Economic
Education Study Program, Faculty of Economics, Universitas Negeri Makassar. The trial was conducted to determine the response of the lecturers and the students to potential users of economic pocketbook media on a broader trial scale. The assessment results related to the feasibility of content carried out by the lecturers and the students in the trial are presented in Table 6.

Table 6. Product Trial Assessment in terms of Content Eligibility

\begin{tabular}{|c|c|c|c|}
\hline No. & Category & Average Score & Criteria \\
\hline 1 & $\begin{array}{c}\text { Clarity of core } \\
\text { competencies and } \\
\text { basic competencies }\end{array}$ & 4.6 & $\begin{array}{c}\text { Very } \\
\text { Feasible }\end{array}$ \\
\hline 2 & $\begin{array}{c}\text { Relationship between } \\
\text { content and everyday } \\
\text { life }\end{array}$ & 4.7 & $\begin{array}{c}\text { Very } \\
\text { Feasible }\end{array}$ \\
\hline 3 & $\begin{array}{c}\text { Completeness of the } \\
\text { content }\end{array}$ & 4.3 & $\begin{array}{c}\text { Very } \\
\text { Feasible }\end{array}$ \\
\hline 4 & Content attractiveness & 4.8 & $\begin{array}{c}\text { Very } \\
\text { Feasible }\end{array}$ \\
\hline & Total & 18.4 & $\begin{array}{c}\text { Very } \\
\text { Feasible }\end{array}$ \\
\hline
\end{tabular}

Source: Computed data, 2020

The total score of the feasibility assessment of the pocketbook contents was 18.4 , with an average score of 4.6 , so it can be concluded that the mind mapping-based pocketbook in the introductory economics course was very feasible from the content aspect. Furthermore, the assessment results related to linguistic feasibility carried out by the lecturers and the students in the trial are presented in Table 7 .

Table 7. Product Trial Assessment in terms of Language Eligibility

\begin{tabular}{|c|c|c|c|}
\hline No & Category & Average Score & Criteria \\
\hline 1 & $\begin{array}{l}\text { Provisions of the use of } \\
\text { terms } / \text { symbols/codes }\end{array}$ & 4.6 & $\begin{array}{c}\text { Very } \\
\text { Feasible }\end{array}$ \\
\hline 2 & Clarity of sentences & 4.3 & $\begin{array}{c}\text { Very } \\
\text { Feasible }\end{array}$ \\
\hline 3 & $\begin{array}{c}\text { Use of communicative } \\
\text { language }\end{array}$ & 4.2 & $\begin{array}{c}\text { Very } \\
\text { Feasible }\end{array}$ \\
\hline 4 & Presentation wrinkles & 4.4 & $\begin{array}{c}\text { Very } \\
\text { Feasible }\end{array}$ \\
\hline & Total & 17.5 & \\
\hline & Average Score & 4.37 & $\begin{array}{c}\text { Very } \\
\text { Feasible }\end{array}$ \\
\hline
\end{tabular}

Source: Computed data, 2020

The results of the assessment of the pocketbook in terms of linguistic feasibility obtained a score of 17.5 with an average score of 4.37 . Thus, it can be concluded that the mind mapping-based handbook in the introductory economics course was very feasible from the language aspect. Furthermore, the assessment results related to the presentation's feasibility from the lecturers and the students in the trial are presented in Table 8. 
Table 8. Product Trial Assessment in terms of Presentation Eligibility

\begin{tabular}{|c|c|c|c|}
\hline No. & Category & Average Score & Criteria \\
\hline 1 & $\begin{array}{c}\text { Presentation of content } \\
\text { by systematics }\end{array}$ & 4.5 & $\begin{array}{c}\text { Very } \\
\text { Feasible }\end{array}$ \\
\hline 2 & Logical presentation & 4.8 & $\begin{array}{c}\text { Very } \\
\text { Feasible }\end{array}$ \\
\hline 3 & Presentation wrinkles & 4.4 & $\begin{array}{c}\text { Very } \\
\text { Feasible }\end{array}$ \\
\hline 4 & $\begin{array}{c}\text { Presentation of figures, } \\
\text { tables, symbols, and } \\
\text { mind-mapping }\end{array}$ & 4.5 & $\begin{array}{c}\text { Very } \\
\text { Feasible }\end{array}$ \\
\hline 5 & $\begin{array}{c}\text { Completeness of } \\
\text { presentation }\end{array}$ & 4.7 & $\begin{array}{c}\text { Very } \\
\text { Feasible }\end{array}$ \\
\hline & Total & 22.9 & Very \\
\hline & Average Score & 4.58 & Feasible \\
\hline
\end{tabular}

Source: Computed data, 2020.

The results of product trial in terms of presentation feasibility obtained a total score of 22.9 with an average score of 4.58. It can be concluded that the mind mapping-based pocketbook in the introductory economics course was very feasible from the aspect of presentation feasibility. Furthermore, the assessment results related to the feasibility of graphics carried out by the lecturers and the students in the trial are presented in Table 9.

Table 9. Product Trial Assessment in terms of Graphical Eligibility

\begin{tabular}{|c|c|c|c|}
\hline No. & Category & $\begin{array}{l}\text { Average } \\
\text { Score }\end{array}$ & Criteria \\
\hline 1 & Pocketbook size & 4.9 & Very Feasible \\
\hline 2 & $\begin{array}{c}\text { Attractive pocketbook } \\
\text { design }\end{array}$ & 4.8 & Very Feasible \\
\hline 3 & $\begin{array}{c}\text { The practically of } \\
\text { pocketbook }\end{array}$ & 4.5 & Very Feasible \\
\hline 4 & Use of letters & 4.5 & Very Feasible \\
\hline 5 & $\begin{array}{c}\text { Readability of writing } \\
\text { sentences }\end{array}$ & 4.8 & Very Feasible \\
\hline 6 & $\begin{array}{l}\text { Proportional font size } \\
\text { compare to books }\end{array}$ & 4.8 & Very Feasible \\
\hline 7 & $\begin{array}{l}\text { Attractive pocketbook } \\
\text { cover }\end{array}$ & 4.9 & Very Feasible \\
\hline & Total & 33.2 & \\
\hline & Average Score & 4.74 & Very Feasible \\
\hline
\end{tabular}

Source: Computed data, 2020.

Table 9 shows the total score for assessing the feasibility of the pocketbook graphic. It was 33.2 , with an average score of 4.74. So, it can be concluded that the mind mapping-based pocketbook in the introductory economics course was in a very feasible aspect of the feasibility of the graphics. An overall economic pocketbook product evaluation was carried out to measure product development goals in the evaluation stage. Revisions were made based on the evaluation results to improve the developed media according to students' needs and the demands of a national curriculum based on higher education competencies regarding the Indonesian National Qualifications Framework (KKNI). After conducting the trials as explained before, it can be concluded that the mind mapping-based pocketbook was very feasible from the aspects of content, language, presentation, and graphics. Thus, the pocketbook that has been tested was ready to be published massively.

In the classroom's learning process, the learning media used, including pocketbooks, must be relevant to the learning content [16]. In learning, the use of media is based on the content of learning. It must accommodate the learning subject correctly so that lecturers must identify essential and non-essential points in designing learning media. For the sake of students' learning convenience, the contents of the pocketbook must be precise. The contents can be divided into four parts: literal descriptions of basic economic theory, derivation of mathematical formulas, changes in numbers and tables, and case studies. Therefore, when making economic learning media, the lecturers must confirm that the pocketbook learning media must summarize the learning content into several main points. The lecturers display them in the pocketbook media using simple words and highlight key concepts with the hope that the students can become a learning center [17] [18].

\section{Conclusions}

Based on the process of developing the economic pocketbook, the development of mind mapping-based pocketbook media in the introductory economics course at the Faculty of Economics, Universitas Negeri Makassar consisted of five stages, namely analysis, design, development, implementation, and evaluation.

Based on the results of validation conducted by the content experts and the media experts on the feasibility of the content and language aspects, mind mapping-based handbooks on the introductory economics course at the Faculty of Economics, Universitas Negeri Makassar were in the very feasible category. Likewise, with the results of product trials and assessed by the lecturers and the students, it was found out that mind mapping-based pocketbook was very feasible in terms of content, language, presentation, and graphics so that the handbook that has been tested was ready to be published massively.

\section{Acknowledgements}

We would like to thank the Research Institution of Universitas Negeri Makassar and Faculty of Economics, Universitas Negeri Makassar, Indonesia, for their financial support of this research, and to anonymous reviewers for excellent comments and suggestions for this paper. 


\section{REFERENCES}

[1] Hasan M., St. Hatidja., Rasyid RA, Nurjanna, Walenta, AS., Tahir J., Haeruddin MIM, "Entrepreneurship Education, Intention, and Self Efficacy: An Examination of Knowledge Transfer within Family Businesses," Entrepreneurship and Sustainability Issues, vol. 8, no. 1, pp. 526-538, 2020. DOI: 10.9770/jesi.2020.8.1(37)

[2] Hasan M., Musa CI., Arismunandar, Azis M., Tahir T, "Positive Psychological Capital, Market Orientation, and Business Performance of Family Business in the Culinary Sector: a Research Study," Economics and Sociology, vol. 13, no. 3, pp. 97-112, 2020. DOI: 10.14254/2071-789X.202 $0 / 13-3 / 7$

[3] Shiller RJ, "How Should the Financial Crisis Change How We Teach Economics?" The Journal of Economic Education, vol. 41, no. 4, pp. 403-409, 2010. DOI: 10.1080/00220485. 2010.510409

[4] Walstad WB, Rebeck K, "Teacher and Student Economic Understanding in Transition Economies," Journal of Economic Education, vol. 3, no. 2, pp. 57-67, 2001. DOI: $10.2307 / 1183215$

[5] Cohen E, Cohn S, "Graphs and Learning in Principles of Economics," American Economic Review, vol. 84, no. 2, pp. 197-200, 1994. URL: http://www.jstor.org/stable/2117828

[6] Becker, WE. "The Use of Mathematics and Statistics in the Teaching and Learning of Economics," in Teaching Undergraduate Economics: A Handbook for Instructors, McGraw-Hill, 1998, pp. 127-139.

[7] Bosshardt W, "Student Drops and Failure in Principle Courses," Journal of Economic Education, vol. 35, no. 2, pp. 111-128, 2004. DOI: 10.3200/JECE.35.2.111-128

[8] Finnie R, Qiu T, "Moving Through, Moving On: Persistence in Post-secondary Education in Atlantic Canada - Evidence from the PSIS," Centre for Education Statistics, 2009, pp. $1-91$.
[9] Dinar M, Hasan M, "Pengantar Ekonomi: Teori dan Aplikasi," CV. Nur Lina Bekerjasama dengan Pustaka Taman Ilmu, 2018, pp. 1-205.

[10] Hasan M, Azis M, "Pembangunan Ekonomi \& Pemberdayaan Masyarakat: Strategi Pembangunan Manusia dalam Perspektif Ekonomi Lokal," CV. Nur Lina Bekerjasama dengan Pustaka Taman Ilmu, 2018, pp. 1-523.

[11] Van Wyk MM, "Effectiveness of the Training of Teachers Project in Economics Education in Free State Secondary Schools," Journal of Social Science, vol. 30, no. 3, pp. 243-250, 2012. DOI: 10.1080/09718923.2012.11893001

[12] Tschannen-Moran M, Woolfolk HA, "Teacher Efficacy: Capturing and Elusive Construct," Teaching and Teacher Education, vol. 17, no. 1, pp. 783-805, 2001. DOI: $10.1016 / \mathrm{S} 0742-051 \mathrm{X}(01) 00036-1$

[13] Darling-Hammond L, Bransford J, "Preparing Teachers for a Changing World: What Teachers Should Learn and be able to do," Jossey-Bass, 2005, pp. 1-441.

[14] Sink DL, "Design Models and Learning Theories for Adults," American Society for Training and Development, 2014, pp. 181-199.

[15] Molenda, M, "In Search of the Elusive ADDIE Model," Performance Improvement, vol. 42, no. 5, pp. 34-36, 2003. DOI: $10.1002 /$ pfi.4930420508

[16] Mappe N, Hasan M, "Penerapan Model Pembelajaran Kooperatif Tipe NHT untuk Meningkatkan Hasil Belajar Siswa Pada Mata Pelajaran Ekonomi di Kelas XI IPS 2 SMA Negeri 5 Makassar," Jurnal Economix, vol. 9, no. 1, pp. 107-117, 2016. URL: http://eprints.unm.ac.id/9380/

[17] Becker WE, Watts M, "Teaching Methods in U.S. Undergraduate Economics Courses," Journal of Economic Education, vo. 32, no. 3, pp. 269-279, 2001. DOI: $10.2307 / 1183384$

[18] Ding M, Li H, "On the Application of Multimedia in Economics Teaching," International Education Studies, vol. 4, no. 3, pp. 88-90, 2011. DOI: 10.5539/ies.v4n3p88 